\title{
PENINGKATAN HASIL BELAJAR IPA MELALUI PENERAPAN MODEL PEMBELAJARAN OUTDOOR CLASS PADA SISWA TUNANETRA KELAS XI SLB N 1 BANTUL YOGYAKARTA
}

\author{
Endang Sri Lestari \\ SLB N 1 Bantul, Yogyakarta \\ Email: lestaricahyoadi818@gmail.com
}

\begin{abstract}
Abstrak
Penelitian ini bertujuan meningkatkan hasil belajar IPA pada siswa tunanetra melalui penerapan Model Pembelajaran Outdoor Class di SLB N 1 Bantul Yogyakarta. Penelitian menggunakan pendekatan penelitian tindakan kelas. Desain penelitian menggunakan Model Kurt Lewin dengan dua siklus dimana setiap siklus terdiri dari empat tahapan kegiatan, yaitu perencanaan, pelaksanaan observasi dan refleksi. Masing-masing siklus diselesaikan dalam dua pertemuan. Penelitian melibatkan siswa tunanetra kelas XI di SLB N 1 Bantul Tahun Pelajaran 2016/2017. Teknik pengumpulan data dilakukan melalui tes, wawancara, observasi dan dokumentasi. Analisis data dilakukan dengan pendekatan deskriptif kuantitatif. Berdasarkan hasil penelitian dapat disimpulkan bahwa hasil belajar IPA siswa tunanetra kelas XI di SLB N 1 Bantul dapat ditingkatkan melalui penerapan Model Pembelajaran Outdoor Class. Hal ini dapat dilihat dari rata-rata peningkatan prosentase ketuntasan belajar siswa.
\end{abstract}

Kata kunci: hasil belajar, IPA, tunanetra, Outdoor Class.

\begin{abstract}
This study aims to improve the learning outcomes of science for blind students through the application of the Outdoor Class Learning Model in SLB N 1 Bantul Yogyakarta. Research uses a class action research approach. The research design uses the Kurt Lewin Model with two cycles where each cycle consists of four stages of activity, namely planning, observing and reflecting. Each cycle is completed in two meetings. The study involved blind students in class XI at SLB N 1 Bantul in the 2016/2017 Academic Year. Data collection techniques are done through tests, interviews, observations and documentation. Data analysis was performed with a quantitative descriptive approach. Based on the results of the study it can be concluded that the learning outcomes of the XI grade XI students at SLB $N 1$ Bantul can be improved through the application of the Outdoor Class Learning Model. This can be seen from the average increase in the percentage of students' mastery learning.
\end{abstract}

Keywords: learning outcomes, Natural Sciences, visually impaired, Outdoor Class.

\section{PENDAHULUAN}

Proses belajar berlangsung selama rentang kehidupan individu sebagai upaya perubahan dalam pandangan, sikap, pemahaman atau kombinasi dari semuanya. Menurut Suryabrata (2007), akan terjadi perubahan perilaku sebagai konsekuensi yang diperoleh melalui proses belajar. Kurikulum 
Nasional mensyaratkan pencapaian hasil belajar pada ranah pengetahuan, sikap dan keterampilan (Kemendikbud, 2014). Diperkuat dengan Permendikbud Nomor 22 Tahun 2016 tentang Standar Proses Pendidikan Dasar dan Menengah, bahwa pembelajaran harus memberikan peluang bagi peserta didik untuk menguasai kompetensi yang diperlukan pada abad 21 yaitu kemampuan berpikir kritis (critical thinking), kreativitas (creativity), bekerja sama (collaborative), dan berkomunikasi (communicative).

Pada praktiknya tidaklah mudah merealisasikan harapan tersebut, terlebih bagi peserta didik berkebutuhan khusus tunanetra. Keterbatasan visual yang mereka alami menjadi faktor penghambat bagi perolehan konsep dari sekitarnya, terutama konsep mengenai alam yang mensyaratkan lebih banyak keterlibatan indra visual. Data Provinsi DIY di mana siswa tunanetra berada pada populasi tersebut memberikan gambaran menurunnya rata-rata nilai Ujian Nasional. Rata-rata pada 2014/2015 mencapai 61,14 pada tahun 2015/2016 turun menjadi 57,41. Berdasarkan hasil observasi di Kabupaten Bantul diketahui bahwa rata-rata nilai Ujian Nasional untuk Mata Pelajaran IPA pada tahun 2012/2013 66,80; tahun 2013/2014 mengalami peningkatan menjadi 72,00 tetapi masih di bawah kriteria kelulusan; dan tahun 2014/2015 kembali menurun menjadi 71,28.

Kondisi tersebut mencerminkan kompleksitas persoalan yang terjadi dalam dunia pendidikan tidak terkecuali Pendidikan Khusus. Sebuah ironi tengah berlangsung, di mana persoalan muncul justru pada saat kemudahan aksesibilitas dan daya dukung pendidikan bagi efektivitas proses pembelajaran telah terpenuhi.

Pembelajaran IPA merupakan proses aktif yang mensyaratkan keterlibatan hampir semua alat indera, seluruh proses berpikir, dan berbagai macam gerakan otot untuk mengakses lingkungan alam di sekitarnya. Pembelajaran IPA dapat menjadi wahana bagi peserta didik untuk mempelajari diri sendiri dan alam sekitar untuk menyelesaikan persoalan dalam kehidupan sehari-hari (Kemendikbud, 2014). Namun membelajarkan materi IPA bukan persoalan mudah, terlebih bagi seorang tunanetra yang kehilangan saluran informasi dari indra visualnya. Menurut Soemantri (2004), keterbatasan tunanetra dalam berinteraksi dengan lingkungan menyebabkan beberapa hambatan diantaranya adanya kecenderungan immobilitas, keteratasan konsep mengenai benda-benda di sekitarnya, dan meniru secara verbal (verbalisme).

Keterbatasan visual tunanetra ini berimplikasi pada pemenuhan pengalaman konkret dari objek dan situasi visual dalam proses pembelajaran. Kondisi tersebut akan berdampak permasalahan pembelajaran di kelas. Sebagaimana hasil temuan peneliti di kelas XI tunanetra di SLB N 1 Bantul diketahui bahwa rata-rata ketuntasan belajar siswa mencapai $45 \%$, sementara kriteria ketuntasan minimal yang ditetapkan untuk mata pelajaran IPA sebesar 70\%. Temuan tersebut didukung data hasil observasi dan wawancara pendahuluan, diperoleh data bahwa rendahnya hasil belajar IPA kelas XI tunanetra di SLB N 1 Bantul dipengaruhi oleh pendekatan pembelajaran yang tidak tepat. Metode yang digunakan selama ini adalah diskusi informasi dan tanya jawab. Siswa menerima informasi satu arah dari guru, sehingga kreativitas tidak berkembang karena cenderung berpusat pada guru (teacher oriented). Pembelajaran terasa menjenuhkan karena situasi kelas gaduh, hal ini dapat dipahami mengingat keterbatasan kondisi fisik ruang kelas, diketahui bahwa dalam satu ruang kelas digunakan untuk 3 rombongan belajar. 
Siswa tunanetra memerlukan pengalaman konkret melalui berinteraksi langsung dengan sumber belajar untuk mengembangkan pengetahuan tentang benda di sekelilingnya. Menurut Rea (2008), pembelajaran yang memberi peluang bagi perolehan pengalaman langsung dari sumber belajarnya adalah pembelajaran luar kelas atau outdoor class. Pembelajaran luar kelas agar bermakna bagi perolehan pengetahuan maka perlu diorganisasi dalam bentuk model pembelajaran. Untuk itu, tindakan yang dipilih untuk mengatasi masalah dalam pembelajaran IPA pada penelitian ini adalah menggunakan Model Pembelajaran Outdoor Class.

Hasil penelitian Cahyono (2016) mengungkap bahwa penerapan Model Pembelajaran Outdoor dapat meningkatkan motivasi dan hasil belajar IPA pada siswa SMP. Temuan ini mendukung hasil penelitian Rea (2008), bahwa penggunaan metode outdoor dalam kelompok kolaboratif dapat menambah semangat dan motivasi siswa untuk belajar.

Model Pembelajaran Outdoor Class dipilih sebagai tindakan untuk mengatasi permasalahan pembelajaran IPA bagi siswa tunanetra kelas XI di SLB N 1 Bantul dengan pertimbangan bahwa IPA berkaitan dengan pengungkapan fenomena alam, sedangkan tunanetra memerlukan pengalaman konkret mengenai lingkungan alamnya dengan demikian membawa anak sedekat mungkin dengan lingkungan alam merupakan cara paling efektif bagi perolehan pengetahuan mereka. Hasil penelitian Fjortoft (2000) dan Malone (2003) sebagaimana dipublikasikan oleh Surahman (2009) menunjukkan bahwa Outdoor Class merupakan pilihan favorit bagi anak. Pemikiran anak berkembang lebih baik jika diberi kebebasan berinteraksi dengan alam.

Penelitian ini mendesak dilakukan untuk mengatasi masalah pembelajaran IPA, sedikitnya dipengaruhi oleh dua alasan, (1) Materi Optik memiliki karakteristik berbeda dengan objek kajian IPA yang lain, yaitu bersifat abstrak bagi peserta didik tunanetra, sulit dibelajarkan melalui pengalaman pengindraan seperti yang dilakukan pada anak awas, (2) hambatan pemahaman suatu konsep akan berdampak terhadap penguasaan konsep pada tahapan berikutnya.

Model belajar yang tidak tepat diindikasikan sebagai faktor utama yang mempengaruhi rendahnya hasil belajar IPA. Untuk itu, penulis melakukan penelitian tindakan untuk mengatasi rendahnya hasil belajar IPA dengan Model Pembelajaran Outdoor Class.

\section{Model Pembelajaran Outdoor Class}

Model pembelajaran diartikan kerangka konseptual yang menggambarkan prosedur sistematis dalam mengorganisasikan pengalaman belajar untuk mencapai tujuan belajar (Supriyono, 2009). Sementara pembelajaran luar kelas (outdoor class) diartikan kegiatan pembelajaran yang didesain di luar kelas dengan menggunakan konteks real life dengan banyak cara dan sifatnya lebih fleksibel.

Model Pembelajaran Outdoor Class dalam penelitian ini dikembangkan dari Teori Rea (2008) dan Cahyono (2016) selanjutnya diintegrasikan dengan pendekatan sain (scientific approach) yang didesain awal oleh John Dewey (1933) dan ahli Psikologi Kognitif Jerome Bruner (1966), untuk selanjutnya telah dikembangkan secara meluas dalam pembelajaran di berbagai jenjang pendidikan. Sintaks Model Pembelajaran Outdoor Class dalam penelitian ini disajikan pada tabel berikut: 
Tabel 1. Sintaks Model Pembelajaran Outdoor Class

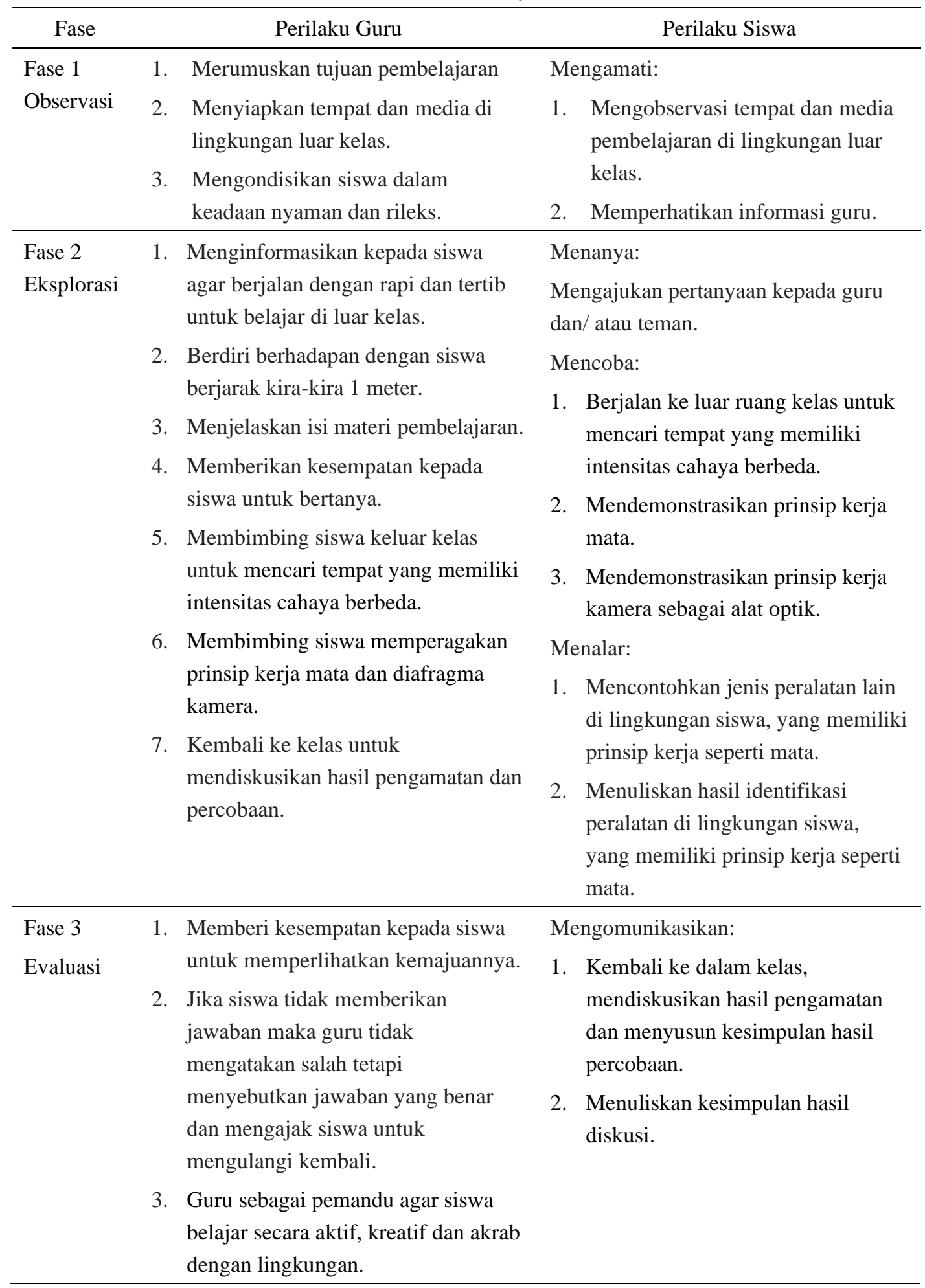


Menurut Wright (Slavin, 2007) Model Outdoor Class memiliki beberapa kelebihan lain, seperti mengembangkan harga diri (self esteem) dan personal self, rasa tanggung jawab, kemampuan kerja sama dan kepedulian terhadap teman. Model Outdoor Class juga memiliki kelemahan yaitu diperlukan waktu yang lebih lama. Kelemahan ini dapat diatasi dengan cara menyajikan materi pembelajaran dalam bentuk tema, sehingga dalam satu aktivitas pembelajaran kita dapat mengintegrasikan beberapa muatan pelajaran.

\section{METODE PENELITIAN}

Penelitian ini dilaksanakan di SLB N 1 Bantul Yogyakarta Tahun Pelajaran 2016/ 2017. Penelitian ini menggunakan pendekatan penelitian tindakan kelas (classroom action research). Desain penelitian ini menggunakan Model Kurt Lewin sebagaimana skema berikut ini:

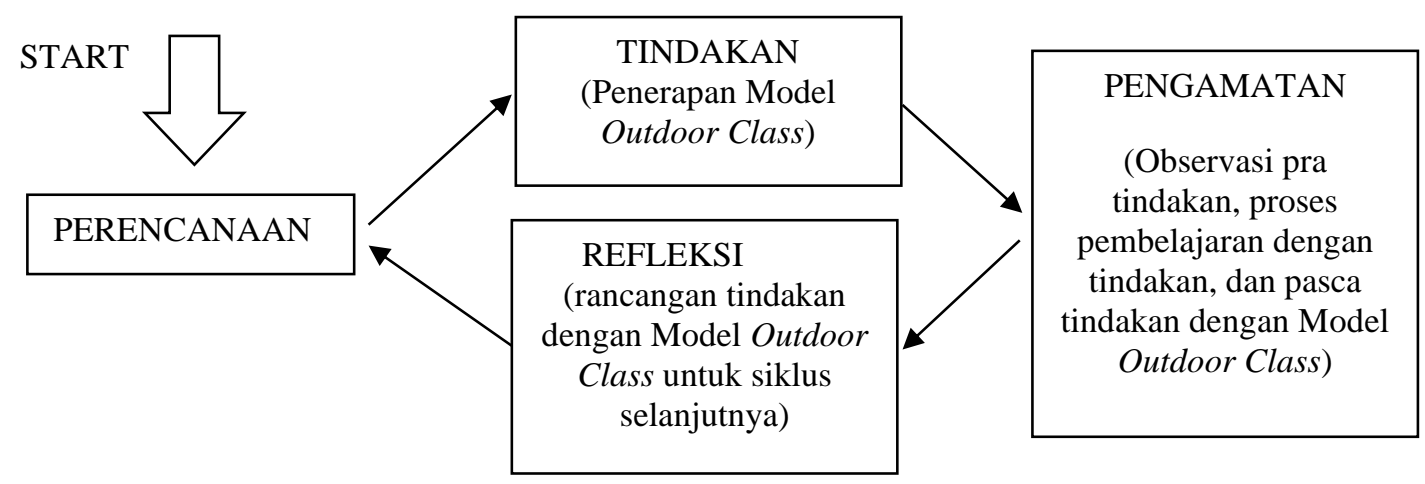

Gambar 1. Model Kurt Lewin

Penelitian dilakukan menggunakan dua siklus, masing-masing siklus terdiri dari dua pertemuan yang diselesaikan dalam waktu dua bulan, yaitu bulan September sampai Oktober 2016. Subjek terdiri dari dua siswa tunanetra kelas XI SLB N 1 Bantul Yogyakarta. Subjek I merupakan tunanetra yang masih memiliki sisa penglihatan (low vision), mampu membedakan cahaya gelap dan terang, mampu membedakan warna dan mampu membaca huruf awas dengan font 20. Sedangkan subjek II termasuk tunanetra yang masih memiliki sisa penglihatan (low vision) disertai dengan hambatan fungsi motorik. Teknik pengumpulan data dilakukan dengan tes, wawancara dan observasi. Instrumen tes terdiri dari 20 item soal pilihan ganda, digunakan untuk mengukur pencapaian kompetensi pengetahuan pada materi Optik dalam pembelajaran IPA. Instrumen tes disusun berdasarkan kisi-kisi soal yang mengacu pada Kurikulum Tingkat Satuan Pendidikan untuk kelas XI tahun 2016/2017. Aspek yang diamati dalam observasi meliputi aktivitas peserta didik dan kinerja guru dalam pembelajaran. Peneliti mengumpulkan informasi menggunakan pedoman observasi berdasarkan kisi-kisi yang mencakup aspek-aspek pembelajaran dalam Model Outdoor Class. Terdapat 20 item pernyataan mengenai aktivitas siswa dan 20 item pernyataan mengenai aktivitas guru. Sedangkan wawancara digunakan untuk mengungkap sikap siswa terhadap pelaksanaan pembelajaran IPA dengan Model Pembelajaran Outdoor Class. Peneliti mengumpulkan informasi menggunakan pedoman wawancara berisi 10 pertanyaan mengenai sikap siswa terhadap pelaksanaan Model Outdoor Class. Selanjutnya data yang diperoleh dianalisis menggunakan pendekatan deskriptif kuantitatif. 
Keberhasilan dalam penelitian dapat diamati melalui peningkatan hasil belajar dengan indikator dapat menjawab pertanyaan secara lisan maupun tertulis, nilai tes setelah tindakan (post test) lebih tinggi dari nilai pre test.

\section{HASIL DAN PEMBAHASAN}

\section{Hasil Pra Siklus}

Kondisi pembelajaran IPA sebelum dilakukan penelitian tindakan adalah dengan menggunakan metode diskusi informasi dan memanfaatkan berbagai media pembelajaran yang tersedia. Guru memberikan informasi satu arah dan dibantu dengan media audio untuk memberikan penguatan selanjutnya dilakukan penugasan.

Metode tersebut terbukti tidak efektif, materi masih dianggap abstrak sehingga siswa kesulitan memahami informasi guru, akibatnya pada waktu dilakukan tagihan soal, siswa kesulitan menjawab. Hal ini dapat dilihat dari rata-rata nilai ulangan harian pada Kompetensi Dasar 5.3 Mendeskripsikan alat optik dan penerapannya dalam kehidupan sehari-hari, pada tabel 2 berikut ini:

Tabel 2. Skor ulangan harian Mata Pelajaran IPA Materi Optik sebelum siklus.

\begin{tabular}{lllll}
\hline No & Subjek & Total skor & Skor perolehan & Persentase pencapaian \\
\hline 1 & NDA & 50 & 20 & $40 \%$ \\
\hline 2 & MR & 50 & 25 & $50 \%$ \\
\hline Rata-rata & & 22,5 & $45 \%$ \\
\hline
\end{tabular}

Berdasarkan tabel di atas dapat diketahui bahwa perolehan hasil belajar siswa masih berada di bawah Kriteria Ketuntasan Minimal (KKM). KKM yang ditetapkan sebesar 70\%, sementara persentase hasil belajar siswa baru mencapai $45 \%$.

\section{Hasil Siklus I}

Pada siklus I peneliti mulai menggunakan Model Pembelajaran Outdoor Class yang dimodifikasi untuk siswa tunanetra. Sintaks Model Pembelajaran Outdoor Class terdiri 3 fase, yaitu (1) Observasi, (2) Eksplorasi, (3) Evaluasi. Sintaks dalam Model Pembelajaran Outdoor Class diselesaikan dalam satu siklus yang terdiri dari kegiatan perencanaan (planning), pelaksanaan (acting), observasi dan refleksi (reflecting).

Pelaksanaan tindakan pada siklus I diawali dengan kegiatan mengamati teks bacaan mengenai Prinsip Kerja Alat Optik dilanjutkan dengan diskusi dan tanya jawab, selanjutnya melakukan praktik menggunakan model diafragma di lapangan (tempat yang mendapat intensitas sinar matahari cukup dan yang kurang mendapat sinar), selanjutnya kembali ke kelas untuk menyusun laporan hasil percobaan dan presentasi.

Data hasil belajar IPA setelah tindakan dikumpulkan dengan menggunakan tiga instrumen yaitu tes, observasi, dan wawancara. Data hasil tes dapat diamati pada tabel 3 berikut ini: 
Tabel 3. Skor hasil tes pasca siklus I

\begin{tabular}{lccccccc}
\hline No & Subjek & \multicolumn{2}{c}{ Kemampuan awal } & \multicolumn{2}{c}{ Pasca siklus I } & \multicolumn{2}{c}{ Peningkatan } \\
\cline { 2 - 9 } & Skor & $\begin{array}{c}\text { Pencapaian } \\
(\%)\end{array}$ & Skor & $\begin{array}{c}\text { Pencapaian } \\
(\%)\end{array}$ & Skor & $\begin{array}{c}\text { Pencapaian } \\
(\%)\end{array}$ \\
\hline 1 & NDA & 20 & 40 & 25 & 50 & 5 & 10 \\
\hline 2 & MR & 25 & 50 & 30 & 60 & 5 & 10 \\
\hline Rata-rata & 22,5 & 45 & 27,5 & 55 & 5 & 10 \\
\hline
\end{tabular}

Tabel di atas menunjukkan adanya peningkatan hasil belajar sebesar $10 \%$ pada subjek I yaitu dari 40\% pada pra-siklus menjadi 50\% pada siklus I. Sedangkan subjek II terjadi peningkatan hasil belajar sebesar $10 \%$ yaitu dari $50 \%$ pada pra siklus menjadi $60 \%$ pada siklus I. Dengan demikian rata-rata hasil belajar pada seluruh subjek penelitian pasca tindakan siklus I mengalami peningkatan tetapi masih di bawah KKM yang ditetapkan sebesar 70\%.

Data tersebut didukung dengan hasil observasi yang dilaksanakan terhadap keseluruhan tahapan kegiatan pembelajaran. Hasil observasi pada siklus I menunjukkan bahwa dalam pelaksanaan terjadi peningkatan keaktifan, perhatian dan minat siswa dalam pembelajaran IPA. Namun pada tahapan membaca teks memerlukan waktu relatif lama. Selain itu pada tahap mendemonstrasikan model diafragma kamera, siswa kesulitan menemukan lapang pandang. Oleh karena itu diperlukan upaya perbaikan pembelajaran pada siklus II dengan cara adaptasi teks bacaan dan penyesuaian ukuran lubang kardus.

Diperkuat dengan hasil wawancara terhadap siswa yang menyatakan bahwa siswa merasa senang belajar di luar kelas sebab dapat mengurangi kejenuhan sebagaimana kutipan hasil wawancara berikut:

"Belajar di luar kelas lebih menyenangkan, lebih segar jadi ndak jenuh. Trus jadi lebih tenang juga ndak berisik seperti kalau di kelas sulit konsentrasi. Tetapi agak kecewa belum berhasil mempraktikkan cara diafragma menangkap cahaya".

Secara keseluruhan terjadi peningkatan hasil belajar pasca siklus I, tetapi belum mencapai kriteria pencapaian indikator yang ditetapkan sehingga perlu dilanjutkan siklus berikutnya.

\section{Hasil Siklus II}

Prosedur yang dilakukan pada siklus II berdasarkan hasil refleksi pada siklus I. Adaptasi materi disajikan dalam bentuk tema yaitu "Ayo Mengenal Cahaya". Selain itu adaptasi model diafragma kamera menggunakan kardus berlubang dalam tiga ukuran berbeda (kreasi guru) yang sudah disesuaikan dengan kemampuan siswa dalam menangkap lapang pandang objek.

Data hasil tes pasca siklus II dapat diamati pada tabel 4 berikut ini: 
Tabel 4. Skor hasil tes siklus II

\begin{tabular}{cccccccc}
\hline \multirow{2}{*}{ No } & Subjek & \multicolumn{2}{c}{ Pasca siklus I } & \multicolumn{2}{c}{ Pasca siklus II } & \multicolumn{2}{c}{ Peningkatan } \\
\cline { 2 - 7 } & Skor & $\begin{array}{c}\text { Pencapaian } \\
(\%)\end{array}$ & Skor & $\begin{array}{c}\text { Pencapaian } \\
(\%)\end{array}$ & Skor & $\begin{array}{c}\text { Pencapaian } \\
(\%)\end{array}$ \\
\hline 1 & NDA & 25 & 50 & 40 & 80 & 15 & 30 \\
\hline 2 & MR & 30 & 60 & 45 & 90 & 15 & 30 \\
\hline & & 27,5 & 55 & 42,5 & 85 & 15 & 30 \\
\hline
\end{tabular}

Mengacu tabel di atas diketahui adanya peningkatan hasil belajar sebesar $30 \%$ pada subjek I yaitu dari 50\% pada siklus I menjadi 80\% pada siklus II, sedangkan subjek II dari $60 \%$ pada siklus I menjadi 90\% pada siklus II. Pencapaian hasil belajar siswa melalui hasil tes pasca siklus II di atas KKM, mengacu data ini penelitian dinyatakan berhasil.

Hasil observasi pada siklusi II menunjukkan bahwa dalam pelaksanaan pembelajaran terjadi peningkatan keaktifan, minat dan tanggung jawab siswa dalam pembelajaran IPA. Siswa lebih mudah menerima dan menyampaikan kembali informasi yang didengar melalui media audio dibandingkan dengan ketika diminta membaca sendiri (pada siklus I). Selain itu pada tahap mendemonstrasikan model diafragma kamera kreasi guru tidak mengalami kesulitan lagi, mampu menemukan lapang pandang objek dengan cepat secara mandiri.

Berdasarkan hasil wawancara diketahui bahwa siswa merasa senang belajar di luar kelas sebab dapat mengurangi kejenuhan. Siswa menyampaikan harapan agar lebih banyak diajak belajar mengenal di luar kelas supaya lebih mengenal lingkungan. Sebagaimana kutipan hasil wawancara berikut:

“... Tapi lokasi belajar di luar kelas kurang enak kalo cuma di sekolah aja, kan sudah biasa. Harusnya lokasinya lebih jauh, trus boleh memilih sendiri seperti ke pantai atau di mana kayak piknik."

Secara keseluruhan terjadi peningkatan hasil belajar siswa pasca siklus II. Hasil penelitian sudah mencapai kriteria pencapaian indikator yang ditetapkan.

\section{Pembahasan}

Hasil penelitian menunjukkan terjadi peningkatan hasil belajar IPA setelah menggunakan Model Pembelajaran Outdoor Class. Penelitian ini berhasil disebabkan beberapa perbaikan tindakan yang dilakukan pada siklus II, diantaranya mengubah materi pembelajaran dengan pendekatan tema dalam format audio dan melakukan perubahan ukuran model diafragma kamera sesuai hasil asessment.

Peningkatan hasil belajar IPA setelah menggunakan Model Pembelajaran Outdoor Class berhasil menggeser paradigma pembelajaran dari pembelajaran berpusat pada guru (teacher oriented) menjadi lebih berpusat pada siswa (student oriented). Siswa terlibat aktif mengamati, mengumpulkan informasi sampai mengomunikasikan pengetahuan yang diperoleh. Temuan ini mendukung hasil penelitian yang dilakukan oleh Nastiti et al., (2012); Bambang dan Anwar (2009) yang mengungkap pembelajaran dengan menggunakan proses penemuan dari lingkungan akan dapat meningkatkan pemahaman konsep serta kemampuan memecahkan masalah. 
Model Pembelajaan Outdoor Class relevan dengan karakteristik IPA yang bersifat abstrak bagi tunanetra, sebab siswa dapat berinteraksi langsung dengan sumber belajar di lingkungannya untuk mengobservasi alam dan isinya. Sejalan dengan pendapat Vigotsky bahwa pengetahuan merupakan proses yang tidak terpisahkan dari aktivitas sosial dan budaya. Pengetahuan itu terkait dengan situasi dan kolaboratif (situated and collaborative), tidak disimpulkan dari dalam individu namun dibangun melalui interaksi dengan berbagai objek di dalam budaya tersebut. Santrock (2007) menambahkan, bahwa pengetahuan didistribusikan di antara orang-orang dan lingkungan yang meliputi benda-benda, buku, artefak, perkakas dan komunitas di lingkungan hidup mereka.

Rea (2008) mengungkapkan bahwa penggunaan pendekatan outdoor class dalam pembelajaran bisa menjadi suatu alternatif bagi guru dalam mengajar karena proses pembelajaran pada dasarnya tidak hanya di ruang kelas, tapi dapat juga menggunakan ruang terbuka seperti taman sekolah untuk menambah semangat dan motivasi belajar. Sementara Raharja (2009) menambahkan siswa tunanetra memiliki potensi dan kebutuhan individual yang berbeda, dalam usaha memenuhi kebutuhan tersebut mengharuskan mereka berinteraksi dengan lingkungan.

Model Pembelajaran Outdoor Class dalam penelitian ini berbasis pada pendekatan sain (scientific approach). Siswa melakukan kegiatan pembelajaran untuk menemukan pengetahuan mengenai konsep cahaya menggunakan lingkungan luar kelas sebagai latar dan sumber belajar. Tahapan kegiatan yang dilakukan memenuhi langkah-langkah pendekatan saintifik mulai dari mengamati objek, mengajukan pertanyaan, mengumpulkan informasi, melakukan percobaan sampai dengan mengomunikasikan hasil percobaan/ pengamatan.

Tahapan pengamatan dan diskusi dalam Model Pembelajaran Outdoor Class memberi kesempatan pada siswa untuk mengembangkan keterampilan pengindraan. Sementara tahapan mencoba memberikan pengalaman problem solving melalui penyelesaian proyek/ tugas. Selain itu siswa juga belajar dengan cara mengalami sendiri tahap demi tahap pembelajaran, dengan demikian pendekatan learning by doing juga diterapkan dalam kegiatan ini. Tahapan menanya dan mengomunikasikan meningkatkan keterampilan sosial siswa.

Model Pembelajaran Outdoor Class memfasilitasi siswa untuk berinteraksi dengan lingkungan sekitar sehingga anak berpeluang memperoleh pengetahuan dari lingkungannya secara mandiri maupun bersama temannya. Harsono (2008) menyatakan bahwa pembelajaran dapat terjadi dengan berbagai bentuk antara lain antara siswa dengan aktivitas pembelajaran, siswa dengan lingkungan sumber belajar, dan antara siswa dengan guru atau temannya.

Model Pembelajaran Outdoor Class juga memfasilitasi siswa untuk menyampaikan dan menjelaskan pengalaman belajarnya melalui kegiatan diskusi dan presentasi. Temuan ini mendukung hasil penelitian Magnese dan Nicolls (2004), bahwa tingkat ingatan siswa yang belajar dengan melakukan dan mengomunikasikan mencapai 90\%, sedangkan siswa yang belajar hanya dengan mendengar, membaca atau melihat tingkat ingatannya hanya mencapai kurang dari $50 \%$.

Pada saat pembelajaran berlangsung guru membimbing siswa melakukan serangkaian percobaan untuk memperoleh pengetahuan mengenai cara kerja diafragma pada alat optik. Temuan ini mendukung pendapat Wardani, dkk (2009) bahwa pembelajaran bagi tunanetra harus mengacu pada prinsip kekonkretan yang memungkinkan tunanetra mendapatkan pengalaman secara nyata dari apa yang dipelajarinya. 
Berdasarkan hasil observasi, kepercayaan diri siswa terlihat mengalami peningkatan melalui tahaptahap Model Pembelajaran Outdoor Class. Indikator peningkatan tampak pada perubahan sikap dari siklus I ke siklus II, yaitu pada waktu mengerjakan tugas pada siklus I siswa masih sering bertanya, tetapi pada siklus II siswa terlihat senang dan mandiri.

Indikator lain yang menunjukkan peningkatan kompetensi sikap siswa adalah meningkatnya inisiatif dalam menyelesaikan tugas, tampak ketika subjek mengalami kegagalan saat merancang percobaan diafragma menggunakan kardus maka siswa mencoba berulang-ulang supaya lobang pada kardus dapat dilewati cahaya. Melalui adaptasi materi tematik maka kemampuan kognitif lebih berkembang, siswa tidak hanya kompeten dalam pembelajaran IPA tetapi secara tidak langsung kecakapan akademik lainnya ikut berkembang. Sebagai contoh, dalam mata pelajaran Bahasa Indonesia kemampuan berkomunikasi siswa meningkat karena dibiasakan menceritakan kembali hasil pengamatan di lapangan. Pada mata pelajaran IPS, siswa belajar mengenal kondisi geografis di lingkungan sekitar. Bidang Pendidikan Agama dan Budi Pekerti (PAgBP), siswa dapat meningkatkan rasa syukur siswa atas nikmat Tuhan berupa potensi alam sekitar dan isinya. Kemampuan Orientasi Mobilitas siswa tunanetra juga meningkat karena pembelajaran melibatkan kegiatan mengenal ciri medan (landmark), arah mata angin (compass direction), dan pengakraban diri (selffamiliarization) dengan lingkungannya.

Indikator-indikator tersebut di atas merupakan dimensi dari pencapaian kompetensi hasil belajar siswa. Dengan demikian, dapat dijelaskan bahwa hasil belajar IPA pada siswa tunanetra dapat ditingkatkan dengan Model Pembelajaran Outdoor Class.

\section{KESIMPULAN DAN SARAN}

\section{Kesimpulan}

Berdasarkan hasil penelitian dan pembahasan dapat diambil kesimpulan bahwa:

1. Hasil belajar IPA siswa tunanetra kelas XI di SLB N 1 Bantul dapat ditingkatkan dengan Model Pembelajaran Outdoor Class. Rata-rata hasil belajar pada siklus I sebesar 55\%, sedangkan siklus II diperoleh sebesar $85 \%$, terjadi peningkatan $30 \%$. Target capaian belajar tercapai yaitu nilai rata-rata mencapai KKM.

2. Peningkatan hasil belajar pada siklus I terjadi karena siswa terlibat aktif dalam pembelajaran IPA dengan Model Pembelajaran Outdoor Class. Peningkatan hasil belajar pada siklus II terjadi karena perbaikan tindakan untuk memperbaiki kelemahan-kelemahan pada siklus I.

\section{Saran}

1. Model Pembelajaran Outdoor Class dapat dijadikan alternatif dalam membelajarkan Materi IPA pada lingkup kajian yang lebih luas dan tidak terbatas pada Mata Pelajaran IPA Kelas XI tetapi dapat digunakan pada mata pelajaran dan jenjang lainnya.

2. Bagi peneliti berikutnya, perlu dilakukan jenis penelitian yang sama dengan menambah jumlah siklus agar tercapai hasil belajar yang lebih maksimal. 


\section{DAFTAR RUJUKAN}

Anwar, B. (2017). Pengaruh Collaborative Learning dengan Teknik Jumping Task terhadap Keterampilan Berpikit Kritis \& Hasil Belajar Siswa. Jurnal Pembelajaran Sains, Vol.1, No 2.

Cahyono, A. (2016). Increasing Motivation \& Science Learning Achievement Through the Implementation of Outdoor Cooperative Learning Model in Class VIII SMP 2 Banguntapan Academic Years (2015/2016). Journal of Education and Practice, Vol. 7, No 26.

Harsono, M. B. (2011). Penerapan Metode Pembelajaran Outdoor Study Guna Meningkatkan Aktivitas, Hasil Belajar \& Kemampuan Menyusun Karya Tulis Geografi Materi Pemanfaatan Sumber Daya Alam Siswa Kelas XI IPS-2 SMA Negeri 3 Blitar. UNM: S2 Program Studi Pendidikan Geografi.

Husamah. (2013). Pembelajaran Luar Kelas “Outdoor Learning”. Jakarta: Prestasi Pustaka Karya.

Raharja, D. (2009). Konsep Dasar Orientasi \& Mobilitas. Makalah. Bandung. Universitas Pendidikan Indonesia.

Rea, T. (2008). Alternative Visions of Learning. E-Journal of The British Education Studies Association. BESA.

Santrock, J. W. (2007). Remaja. terj: Benedictine Widyasint. Edisi 11. Jakarta: Erlangga.

Slavin, R. E. (2009). Psikologi Pendidikan. Teori \& Praktik. Edisi ke Delapan. Jilid II, terj. Marianto Samosir. Jakarta: Macanan Jaya Cemerlang.

Soemantri, S. (2007). Psikologi Anak Luar Biasa. Bandung: Refika Aditama.

Suprijono, A. (2009). Cooperative Learning, Yogyakarta: Pustaka Pelajar.

Surahman. (2009). Pengembangan Metode Outdoor Learning Bagi Pembelajaran IPA. Makalah. Yogyakarta: Jurusan Biologi UNY.

Suryabrata, S. (2007). Psikologi Pendidikan. Jakarta: Raja Grafindo Persada.

Tim. (2007). Panduan Pengembangan Pembelajaran IPA Terpadu, Jakarta: Puskur Balitbang Depdiknas.

Permendiknas Nomor 20 Tahun 2016 tentang Standar Kompetensi Lulusan.

Wardani, I. G. A. K., Astati, H.T., \& Somad, P. (2009). Pengantar Pendidikan Luar Biasa. Jakarta: Universitas Terbuka. 